\title{
Repetition and joking in children's second language conversations: playful recyclings in an immersion classroom
}

\author{
Asta Čekaitė and Karin Aronsson
}

\section{Linköping University Post Print}

N.B.: When citing this work, cite the original article.

Original Publication:

Asta Čekaite and Karin Aronsson, Repetition and joking in children's second language conversations: playful recyclings in an immersion classroom, 2004, Discourse studies, (6), 3, 373-392.

http://dx.doi.org/10.1177/1461445604044295

Copyright: Sage

Postprint available at: Linköping University Electronic Press

http://urn.kb.se/resolve?urn=urn:nbn:se:liu:diva-13992 


\title{
Repetition and joking in children's second language conversations. Playful recyclings in an immersion classroom.
}

\author{
Asta Cekaite \& Karin Aronsson \\ Cekaite, A. \& Aronsson, K. (2004). Repetition and joking in children's second language \\ conversations. Playful recyclings in an immersion classroom. Discourse Studies, 6, 373-392.
}

\begin{abstract}
Repetition is often associated with traditional teaching drills. Yet, it has been documented how repetitions are exploited by learners themselves (Duff, 2000). In a study of immersion classroom conversations, it was found that playful recyclings were recurrent features of young learners' second language repertoires. Such joking events were identified on the basis of the participants' displayed amusement, and they often involved activity based jokes (Lampert, 1996) and metapragmatic play, that is, joking about how or by whom something is said. Two types of recyclings: intertextual play and role appropriations were both important features in informal classroom entertainment and in the formation of a community of learners (cf. Rogoff, 1990). In a broad sense, both types of joking contained subversive elements in that they created play zones or 'time out' (cf. Goffman, 1959; Jefferson, 1996) within classroom activities. Moreover, role appropriations were subversive in that they inverted classroom hierarchies.
\end{abstract}

Key words: children's early L2 conversations, repetition, joking events, metapragmatic play, subversion.

\section{Introduction}

In modern methods of second language (L2) teaching, repetition has at times been banned, as in many content based methods, or at best tolerated (Duff, 2000). In contrast, repetition has traditionally been an important tool in the language drills of audiolingual methods of L2 teaching, as ways of shaping 'good habits'. In both cases, repetition has been a central feature of competing language teaching ideologies. On a theoretical note, though, repetition has today been discussed in a novel way, in terms of language automaticity and exposure (Duff, 2000; McLaughlin, 1987), and it has been redefined as an empirical issue (Duff, 2000), rather than merely a matter of theoretical speculations or set ideologies. In line with language socialization paradigms (e.g. Garrett and Baquedano-Lopez, 2002; Ochs, 1988), recycling 
patterns in L2 acquisition need to be studied, as used and not only as a theoretical notion. In line with an emic ethnographic perspective on language acquisition, it is therefore important to see how children themselves use repetition in their first stages of L2 acquisition. Also, there is a growing awareness that repetition has a series of social functions. It can be used playfully, emotionally, expressively or ritualistically (Johnstone, 1994; see also the early work of Keenan, 1977 on toddlers' mutual recyclings). In her analyses of 'say-after-me' routines among Kaluli families in New Guinea, Schieffelin (1990) has shown how repetitions are central features of early language socialization, and somewhat related patterns have been found among Tzeltal speaking Maya families (Brown, 2000). From the pioneering work of Goodwin and Goodwin (1987) it has, for instance, also been shown how so called format tyings (exact or partial repetitions) are important social resources in the teasing and dispute activities of school age children and adolescents.

In the present study, we therefore wish to move beyond language ideology (pro or con repetition), and study how recyclings are indeed used by young L2 learners themselves. As yet, there are but very few studies of children where the role of repetition in L2 acquisition has been documented in-depth. An exception is Pallotti (2000), who shows that repetitions are useful strategies for gaining entrance into multiparty conversations. In a study of early acquisition, Cathcart-Strong (1986) showed how L2 learners (Spanish children in a bilingual pre-school play setting) tend to secure attention in accordance with two maxims: 'to be entertaining' and 'to be persevering'. In a study of L2 acquisition of a Moroccan child in an Italian pre-school setting, Pallotti (2000) demonstrated that children's contributions also need to be neatly coordinated with their co-participants' actions and focus of interest. Pallotti (2000) did not explicitly focus on joking exchanges, but he has added an important third maxim in documenting the importance of timeliness, that is, adapting to the local sequential 
demands of the situation at hand. In the present case, where the focus is on joking events, this can, of course, partly be seen as a special case of 'being entertaining'.

How do children engage in joking interactions before they master a second language? One solution is, in fact, to recycle prior speakers' utterances. Yet, such recycling need not be purely imitative. As discussed by Schwartzman (1978), children's play is rarely imitative in any mechanistic way. In line with Bakhtinian (1981) reasoning, it always contains perspective taking of some kind. In the case of children's jokes, such perspective taking may involve teasing, joking, parody, and are often critical comments on daily life (Schwartzman, 1978). Collusion and other forms of subversion are important aspects of peer play (see also, Blum-Kulka et al, this volume; Aronsson and Thorell, 2002). Telling jokes is just one form of a wide range of humor in daily conversations (Hay, 2001). 'Jokes' are but just one manifestation of acting 'nonserious'(Schegloff, 2001: 1952). In children's interactions, forms of humor besides jokes include fantasy play, silly songs, word play and behavioral forms of humor, such as buffoonery and naughty acts (cf. Lampert, 1996).

Humor is often based on an inversion of normative expectations. 'Jokes, being themselves a play upon forms, can well serve to express something about social forms' (Douglas, 1968: 370). Indirectly, jokes may thus offer us a comment on what are the normal background expectancies in social life. Thereby, when assuming a variety of social roles (when participating in joking events) children can be seen to enhance their understanding of the social organization of everyday life in classroom communities.

Moreover, the present work on classroom recyclings is intimately related to a reorientation toward a focus on classroom communities, rather than on teacher-student relations alone. Sociocultural theory has advocated a redefintion of learning, disassociating it from formal curricula and a traditional focus on teachers' contributions 
(teacher-student knowledge transmission; cf. the 'conduit metaphor', Reddy, 1979). Instead, sociocultural theory has reconceptualized learning as part of social practices within communities of learners (e.g. Lave and Wenger, 1991; Rogoff, 1990). As yet, there is, however, but little ethnographic work on language acquisition within L2 peer communities. A few exceptions are the studies of Pallotti (2000), Willet (1995), as well as work on code-switching among primary school children exploiting code switches between Swedish and English for interactional ends (Cromdal and Aronsson, 2000).

Within empirical studies of foreign language acquisition, a focus on recyclings in local classroom communities can be seen in the work of Rampton (1999) on how FL teaching is recycled in peer group interactions among adolescents as significant resources in performance based identity work. Rampton (2002) also discusses the role of recurrent routines or rituals in classroom life. On a somewhat different note, daily classrooom routines provide frameworks for young learners' participation in classroom conversations that go beyond their present level of linguistic competence (e.g. Kanagy, 1999).

Some recent studies have investigated playfulness in classroom discourse (thereby modifying the notion of 'lesson'). They have, however, been largely limited to teachers' ways of monitoring classroom culture (van Dam van Isselt, 1993; Sullivan, 2000; van Dam, 2002), that is to say teacher's ways of creating time-out from the official business of classroom work. The present study, on the other hand, focuses on children's initiatives that move the classroom discourse into the nonserious realm. Moreover, we will show that children create joking events in a variety of participation frameworks, involving both just another peer, a peer group, the teacher alone or the entire group.

\section{Method}


The present study is a part of a larger investigation of children's L2 socialization in an informal classroom context (on language socialization, cf. Ochs, 1988; Schieffelin, 1990). The main data consist of recordings of everyday peer and teacher-student interactions. The method is also informed by conversation analysis (e.g. Sacks, 1992) and discursive psychology (e.g. Potter, 1997), which means that talk is studied as social action, and in detail. Moreover, such an approach entails a focus on interactional work, e.g. response formats and other sequential patterns.

\section{SETTING}

The classroom data were collected in an immersion classroom for refugee and immigrant children, a so called 'reception classroom (Sw: 'mottagningsklass'), in a Swedish school. The present group was constituted of children in grades 1-3 (aged 7 to 10 years). All the children in a class of nine (four girls and five boys) were beginner learners, who had recently arrived in Sweden.

The class met five days a week, 4-6 hours a day. Most of the children had arrived in Sweden from Iraq, Lebanon, Thailand or Turkey (speaking Arabic, Kurdish, and Thai). All children except Nok, a girl from Thailand, spoke some Arabic. The main teacher in the classroom, Vera, was a native Swedish speaker. An assistant teacher, Fare, assisted the Arabic-speaking children, and Arabic was used extensively in the peer group, as an informal extra lingua franca in the classroom. The names of the teachers, as well as the names of all students have been fictionalized for the sake of anonymity.

The activities ranged from teacher-led book reading or story-telling, sharing time, singing and other activities designed for whole class participation to individual work on task, such as writing and reading, mathematics or aesthetic activities such as working with 
modeling clay. Children's spontaneous contributions were encouraged throughout individual work, as well as during teacher-led activities. Hand raising to bid for attention or a turn was rare, and peer group talk, if not disturbing or interrupting classroom activities, was tolerated. Many activities occurred spontaneously, and educational games (e.g. memory) were recurrently initiated by the teachers.

\section{ANALYTIC UNIT}

The primary analytic units of the present study are children's joking events in daily classroom interactions. We defined as joking events all events that were recognized as humorous by the participants, as displayed in their laughter, or verbal acknowledgments of laughables (Glenn 1989; Jefferson 1979). A joking event may unfold across multiple speaker turns or it can be an unsuccessful 'solitary' attempt marked by a laughter invitation (e.g. giggling or laughter). In the present study, the participants' own orientation to something as funny helped us identify joking events (cf. Sacks 1992 on the so called proof procedure of conversation analysis). Some (but not all) joking events involved recyclings in a broad sense, that is, immediate recyclings of prior speakers' last turns.

Much research on children's development of humour has employed 'prefabricated' jokes to measure individual children's cognitive and linguistic development (Bjorklund, 1989; McGhee 1976). In contrast, the present study of joking events in a formal language instructional setting explores the dialogical architecture of emergent jokes. How do children with only a basic language proficiency create humour, drawing upon pragmatic awareness in everyday interactions? Examples are chosen to illustrate playful recyclings, that is, joking events that involved exact or partial repetitions. Two types of playful recyclings were identified: intertextual play and role appropriations. 


\section{RECORDINGS AND DATA}

The children's classroom interactions as well as their play activities were video recorded during three periods during the school year, covering an early, mid- and late phase of the school year (in all 90 hours of recordings).

In the present analyses, the data from the mid-phase is used. During the mid-period of the data collection, the children had spent between 4 and 7 months in Sweden at school. The data for the study are transcripts of children's on and off-task interactions. In this paper, examples are drawn from a broad range of activities, that are representative of classroom routines, such as singing (Examples 1,2), counting routines (Example 3), address term formulations (Example 4), and picture labellings (Example 6).

The recordings of joking events constitute the main data, but ethnographic field notes have also informed the analysis. The translations have been made by native speakers of English and Arabic, and our ambition has been to preserve the children's original style of speaking as far as possible, including nonnative idioms and grammatical errors.

\section{Playful recyclings}

Obviously, the joking events in the immersion classroom were affected by the present children's restricted proficiency in Swedish. In fact, one of our overriding questions is: in what ways - if any - is it possible to engage in joint joking during early phases of L2 acquisition? What are the verbal and nonverbal resources children draw upon when creating and participating in joking events? Indirectly, though, the present analyses also concern laughable matters in multilingual language classroom (what is funny) as well as the social functions of joking events in such a setting. 
Obviously, most of the present joking merely involved rudimentary forms of spontaneous joking, rather than riddles, puns, story telling or other verbally elaborate forms of joking. Yet, analyses of the present children's interactional repertoires revealed that the joking mode was an important discursive genre in the immersion classroom. By deploying parodic imitations and other recyclings, the children were, in fact, able to construct and participate in joking alignments in a broad range of joking activities. As will be discussed, these recyclings were also often quite artfully designed.

Recycling was thus an important means for creating joking contributions with only a limited L2 repertoire. Two forms of recyclings were recurrently employed in the immersion classroom: intertextual joking and role appropriations. As will be seen, the two forms partly overlap, though, in that all the present role playing events involved intertextuality in a broad sense (Kristeva, 1967). Yet, all intertextual events did not involve role appropriations (cf. Example 1).

\section{INTERTEXTUAL JOKING}

What we call intertextual play involves epistemological play on hybrid presentation modes: such as novel combinations of song lines and personal names, or numbers (counting routines) and personal names. Formulaic routine phrases, prototypical classroom Q-A sequences, counting routines, address routines ('my name is...'), as well as Swedish song lines were all intertextual resources in the creation of joking events. Intertextual joking exploited everyday routines from the classroom community, relating them to incongruent or unexpected aspects of classroom life. For instance, song lines were recycled and integrated into everyday activities in novel and unexpected ways. In work on adult-child conversations in preschools, integrations of text (song) and life (everyday reality) have been discussed in terms of text-tolife intertextuality (Cochran-Smith, 1994). Our examples 1 and 2 similarly illustrate a playful 
incorporation of a proper name in a song text, what we will call a person-in-song intertextual reference.

The children practised songs on a daily basis. In our first example, the teacher aid and the children were singing the 'namnsdags' ('nameday') song, which was routinely sung in chorus every morning (as a daily classroom routine).

Ex 1. (0209.0921). Participants: teacher aid Fare, children: Miran (boy 9), Sawan (boy 9), Layla (girl 10), Rana (girl 8), Ali (boy 7), Fusi (girl 7), Nok (girl 7).

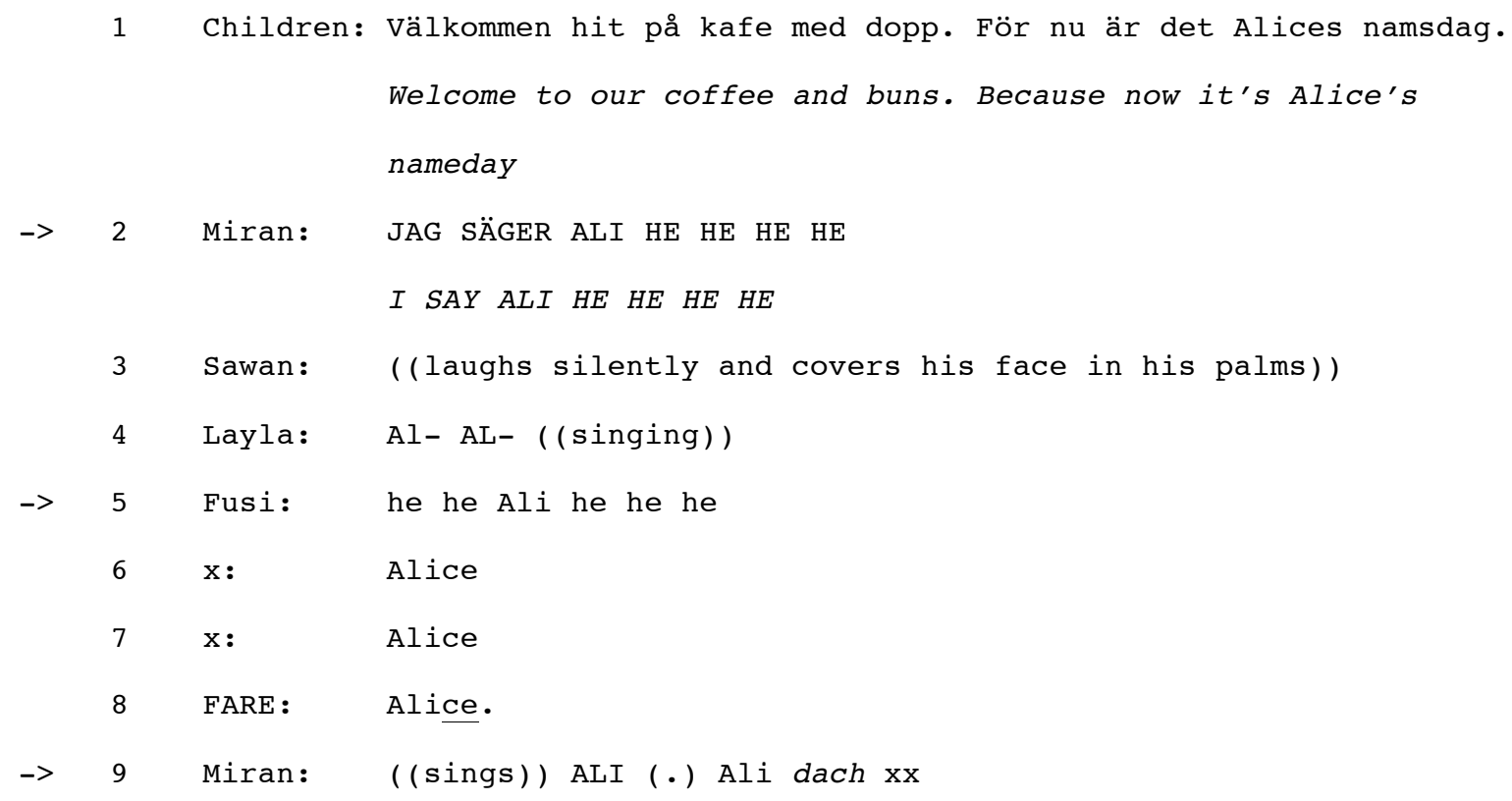

During the song, Miran substitutes the Swedish name 'Alice' with a classmate's Arabic name, 'Ali'. The intertextual substitution is apparently based on phonetic resemblance between the two names: Alice (a girl's name) and Ali (a boy's name).Yet, Miran's playful singing is part of a choral activity and can therefore easily be 'missed' by his co-participants. Miran therefore announces his 'funny' mislabelling to the classroom audience by speaking loudly and laughing (line 2) and by loudly singing the punch line 'ALI' (line 9). Thereby, he presents his self-quoted error (a pun of a sort) not as an example of 'overhearable self-communication, but as collusive asides to the audience' (Goffman, 1981: 309). 
His laughter invitation is taken up by several children, Sawan laughs, covering his face with his hands (line 3), and Fusi repeats the laughable matter in the song (the substituted name, Ali). In a sing song format, Layla playfully repeats the initial syllable of the two names 'Al- al', (line 4). In all, three children orient to his 'funny' line.

Some of the children and the teacher-aid then repeat the correct name. It can be noted that the teacher-aid stresses the final syllable, apparently trying to re-establish classroom order (line 8). Miran, however, continues his playful transformation of the song, now singing the name Ali loudly and making up a nonsense phrase ('Ali dach'), apparently recycling 'dag' ('day' from 'nameday') into another subversive aside to classroom work (line 9). His nonsense phrase can be seen as a type of joking language play. Moreover, it is a type of language play, which involves what Jefferson (1996: 28) has called 'cross-speaker poetics' in that it involves alliteration and sound parallelisms across speaker turns:

M: JAG SÄGER ALI

L: Al- Al

F: Ali

$\mathrm{x}$ : Alice

y: Alice

T: Alice

M: ALI Ali dach

In combining words from two modes (singing and classroom personae), the present language play simultaneously entails metapragmatic play in that the recyclings can be seen as comments on how language is used. In a related paper on the present children's peer play (Cekaite and Aronsson, 2002), we discuss three types of language play genres: phonological and morphological play, mislabellings and puns. In the present data, language play was often 
combined with metapragmatic play genres, e.g. intertextual play and role appropriations (as in the combined phonological and intertextual play in this episode).

In our next example, the children were working individually on math exercises, when the tape recorder played a song "How shall we weave... into".

Ex 2 (0210.1331). Participants: teacher-aid FARE, children: Sawan (9, boy), Fusi (7, girl).

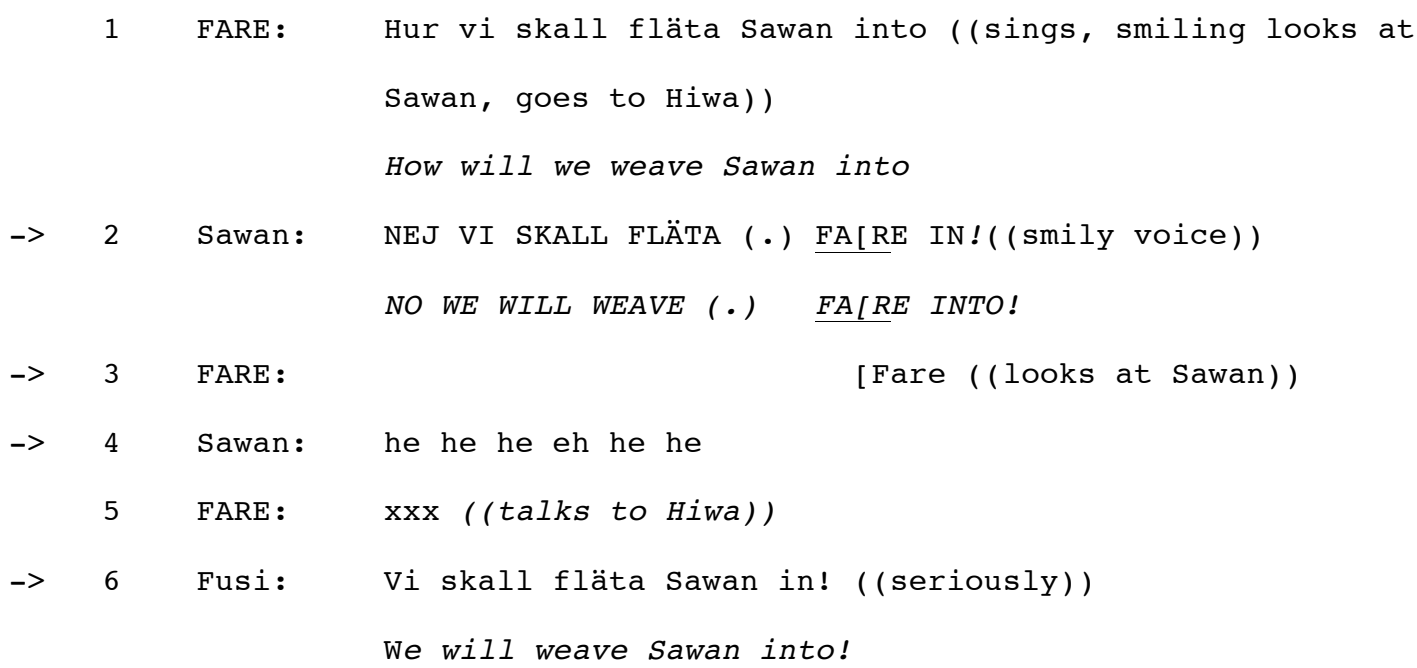

In his singing, the teacher jokingly incorporates Sawan's name into a familiar song (line 1). Sawan recognises the joking character of this kind of association between 'text' (song) and 'life' (his name) and makes a playful commentary by reciting the same verse (line 2), jokingly incorporating the teacher's (Fare's) name. In the present case, the teacher, in fact, aligns with Sawan's joking in that he playfully repeats his own name, that is, the subversive substitution (line 3). Sawan indirectly acknowledges this reciprocal joking by laughing (line 4). The teacher and the child can thus be seen to collaboratively engage in a coordinated playful performance (lines 1- 4). Yet, Sawan's move is also somewhat subversive in that it inverts a traditional classroom hierarchy, as the pupil jokes with the teacher. In any case, Fusi does not align with Sawan's playful mode. In a serious mode, she reiterates the teacher's text (from line 1). Thereby she can also be seen to work toward re-establishing the teacher's authority, or at least classroom 
order. This constitutes yet another case of what Goodwin and Goodwin(1987) have called format tying in that it involves a reuse of features of surface structure of prior utterance: in this case, 'fläta Sawan in' ('weave Sawain into') is recycled as 'fläta Fare in' ('weave Fare into').

Studies of spontaneous joking have demonstrated that laughter is just one way to acknowledge humor in conversation and that appreciation may include more joking (Hay, 2001; Hopper, 1992; Sacks, 1992), playing along with a gag, (Hay, 2001) and repetitions (Hopper and Glen, 1994; Norrick, 1994), etc. As discussed by Sacks (1992, v. I 294-295),' jokes often come in rounds' or as 'first jokes' and 'second jokes'. With minimal means, Sawan is here able to produce such a second joke, recycling the teacher's joke as it were.

In our next example, the joking event is similarly based on intertextual substitution. This time it is combined with an attention call. In the present context, intertextual joking, recurrently served as attention getting devices within the noisy multiparty context of the classroom community. It is certainly a somewhat subtle resource in that the recipient is not addressed directly but is merely 'talked about'.

This time, the item from a routinely practised counting phrase (cardinal numbers) is substituted with a proper name. The children were working individually on mathematics exercises, while the teacher was walking around monitoring their work.

Ex 3 (0210.1346). Teacher-aid FARE. Children: Nok (7 girl), Layla (10 girl).

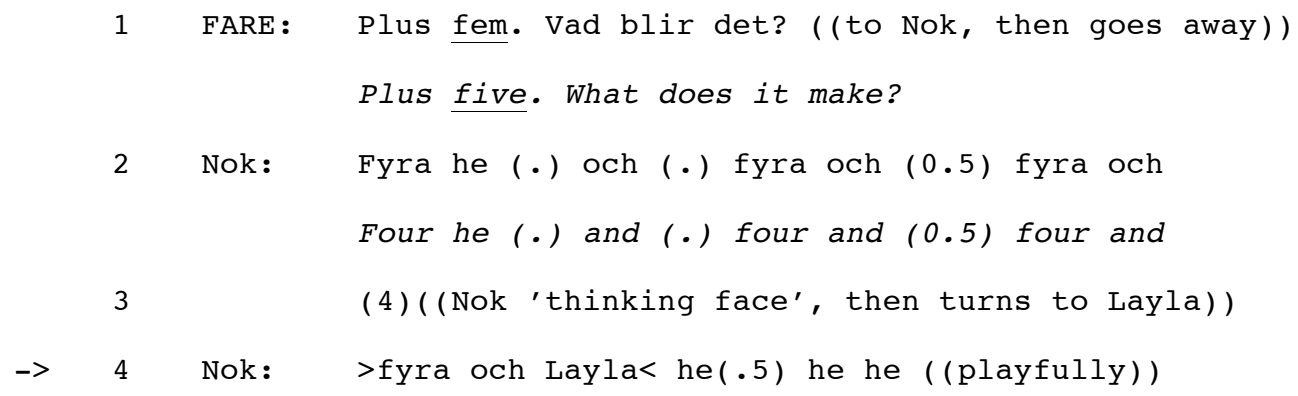


>four and Layla< he (.5) he he

5

6 Nok: Det du? ((leaves her place, reaches for Layla smiling))

That you?

7 Layla: ${ }^{\circ}$ Atta ${ }^{\circ}$

${ }^{\circ}$ Eight ${ }^{\circ}$

8 Nok: he he he ((looks at Layla, moves back to her desk))

9 FARE: Går det bra Layla?

How are you doing Layla?

While doing count aloud operations (adding five to a preceding number), Nok turns to Layla with a smile, incorporating her name into a counting routin 'fyra och Layla' ( 'four and Layla'; line 4). A counting aloud routine is thus transformed into a joking attention call, where integration of a text (here: counting routine) and life (here: a proper name) is employed to invite amusement. The substitution, a first name, flouts the expected paradigmatic frame of counting as a series of numerals. This frame break involves a 'phrase-level semantic contradiction' (Cook, 2000) and is keyed as funny and playful in that Nok smiles and laughs as she delivers her joke (note also her body movements, and the marked tempo of the speech delivery of the 'funny' phrase, which apparently mark a redirection of the conversation). In Goffman's (1974) terminology, the counting operation is thus rekeyed into a joking event (on such switches between serious and nonserious modes, see also Blum-Kulka et.al, this volume).

In the classroom, it was notable that such 'person-in-numbers' (Example 3) or incorporation of a person's name into some other routinely practised text (songs, verses, etc.), as in person-in-song references (Examples 1 and 2), were frequently used to attract the target person's attention. An indication that such metapragmatic play was meant as a 'joking' call for attention can be seen in Nok's next contributions (lines 6 and 8), where she makes a more direct attempt to gain Layla's attention. She playfully identifies Layla 
'that you', as something in a textbook and laughs. Although this attention call is not accomplished through a word substitution, (as in line 4), it is still based on an exploitation of ambiguity with respect to text/life reference. Layla is, however, busy doing her math and does not respond to Nok's playful attention calls.

As can be seen, attention is not something that can be taken for granted in the open environment of a child centered classroom, where a series of activities are going on simultaneously, and where pupils have to be entertaining in order to secure attention and sustained interest. The present findings thus indicate that Cathcart-Strong's (1986) maxims of 'be interesting!' and 'be entertaining!' are also relevant in a formal educational setting.

In work on children's lore (Chukovsky, 1963; Opie and Opie, 1959), it is welldocumented how semantic contradictions can be used for humorous effects in creative and innovative ways of doing reality play. In the present classroom, such contradictions were built on intertextual jokes that apparently emerged from classroom language routines at the time period of the recordings, e.g. vocabulary drills, for instance, involving incongruent uses of nominal phrases, such as' a pair of shoes' -> 'a pair of ...', telling time: 'a quarter past ...'- 'a quarter to ... '- '... past', ‘...to' and counting routines such as 'four and five'.

In sum, such (intertextual) joking events transformed routine classroom activities (e.g. counting aloud) into entertainment. Formulaic expressions and classroom routines from a shared classroom biography thus entered into a variety of joking events in the peer group (Example 3), as well as in joking exchanges with the teachers (Examples 1, 2; see also 4 below). Several of these events simultaneously involved language play (e.g. playful format tyings), but above all, they involved metapragmatic play, in that they could be seen as comments on classroom routines. 


\section{Role appropriations}

The children also exploited their knowledge of teacher-talk and teaching routines in joking events that involved role reversals, e.g. children acting as teachers as it were or subverting the classroom hierarchy by treating the teacher in a playful way. In its simple forms, such joking merely involved repetitions of preceding speakers (cf. Ex 2). What is funny about simple joking that involves role appropriations is not what is said, but who says it. In other words, many of these jokes involve impersonations of teachers, where students speak like teachers as it were. What Goffman (1981) has called 'animation' in his discussion of production formats was thus an important element in classroom improvisations.

In one of our previous examples (Example 2), we could, in fact, see such role appropriations in Sawan's way of joking by recycling the teacher's prior utterance, thereby using his own words in a slightly subversive way. Our next example illustrates a more indirect role appropriation, which involves the child's recycling of prototypical 'teacher talk' (Cazden, 1988; Heath, 1978), that is, a register or expression typically associated with the teacher role within the classroom community. In this case, it involves a teacher's employment of diminutives. The present teachers recurrently employed diminutives, e.g. addressing the children as 'little Nok, 'little Fusi' etc.

Ex 4 (0210.1349) Teacher-aid FARE. Children: two girls, Nok (7) and Layla (10).

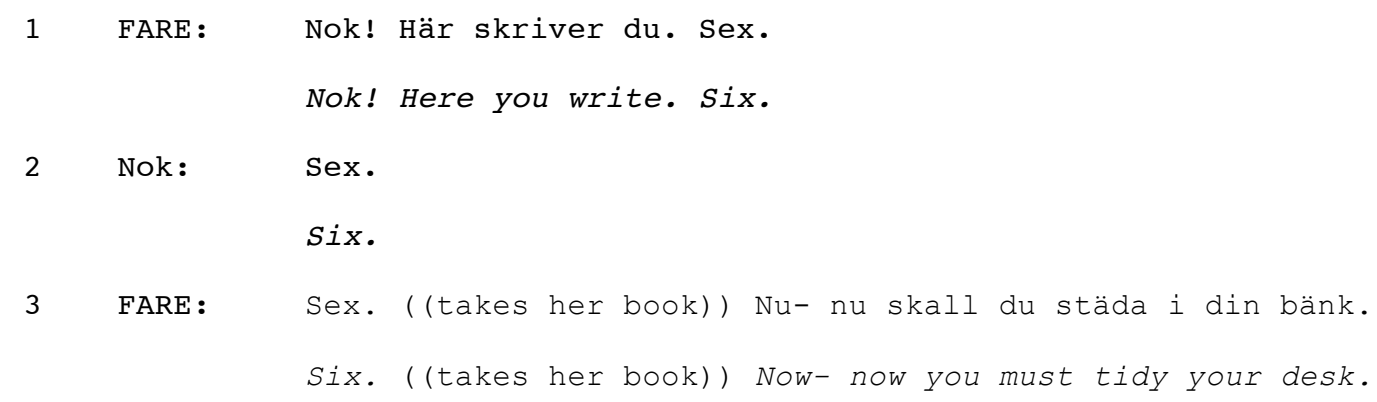


Nok playfully addresses her teacher Fare (line 5), making a joking comment on his going away from her desk. Her utterance is equivocal in two respects. First, Nok positions herself as a teacher in that she employs several features of a teacher talk register: she incorporates an address term which in the present classroom was usually associated with a teacher talking to the children, a diminutive endearment address routine 'little +child's name'. Moreover, she employs a directive 'inte gå' ( 'do not go'; line 5). In sum, Nok introduces a subversive role appropriation when positioning herself as a 'teacher', using teacher's language. Partly parodying a teacher position, she plays on age and status hierarchy relations. It should also be noted that her utterance has two recipients: Fare, who is addressed by his proper name, and Layla, whom Nok addresses through her gaze. The playful nature of her teacher role appropriation is partly validated in her way of smiling collusively at Layla.

This episode illustrates how linguistic and interactional (pragmatic) skills are inseparably intertwined in everyday language use. In her joking contribution (line 5), Nok not only displays her linguistic knowledge of L2, but also her classroom competence, that is, her pragmatic knowledge of what constitutes appropriate (and subversive) classroom behavior when modelling her joking as a playful 
transformations of teacher talk. Address terms signal different degrees of formality/informality, and one aspect of classroom social competence is to master implicit rules of classroom pragmatics (Snow and Blum-Kulka, 2002:331). When playing with address forms (see also, Sawan in Example 2), the children thus simultaneously displayed aspects of their classroom competence.

As demonstrated in an intercultural study of American and Italian children's arguments (Corsaro and Maynard, 1996), format tying can be accomplished both verbally (by attending to the surface structure of the prior utterance) and through embodied action. In the present data, nonverbal action format tying was often an integral element of joking events in the classroom.

Ex 5. (0221.1222) Participants: teacher Vera, class (including Nok (7, girl) and Ali (7, boy).

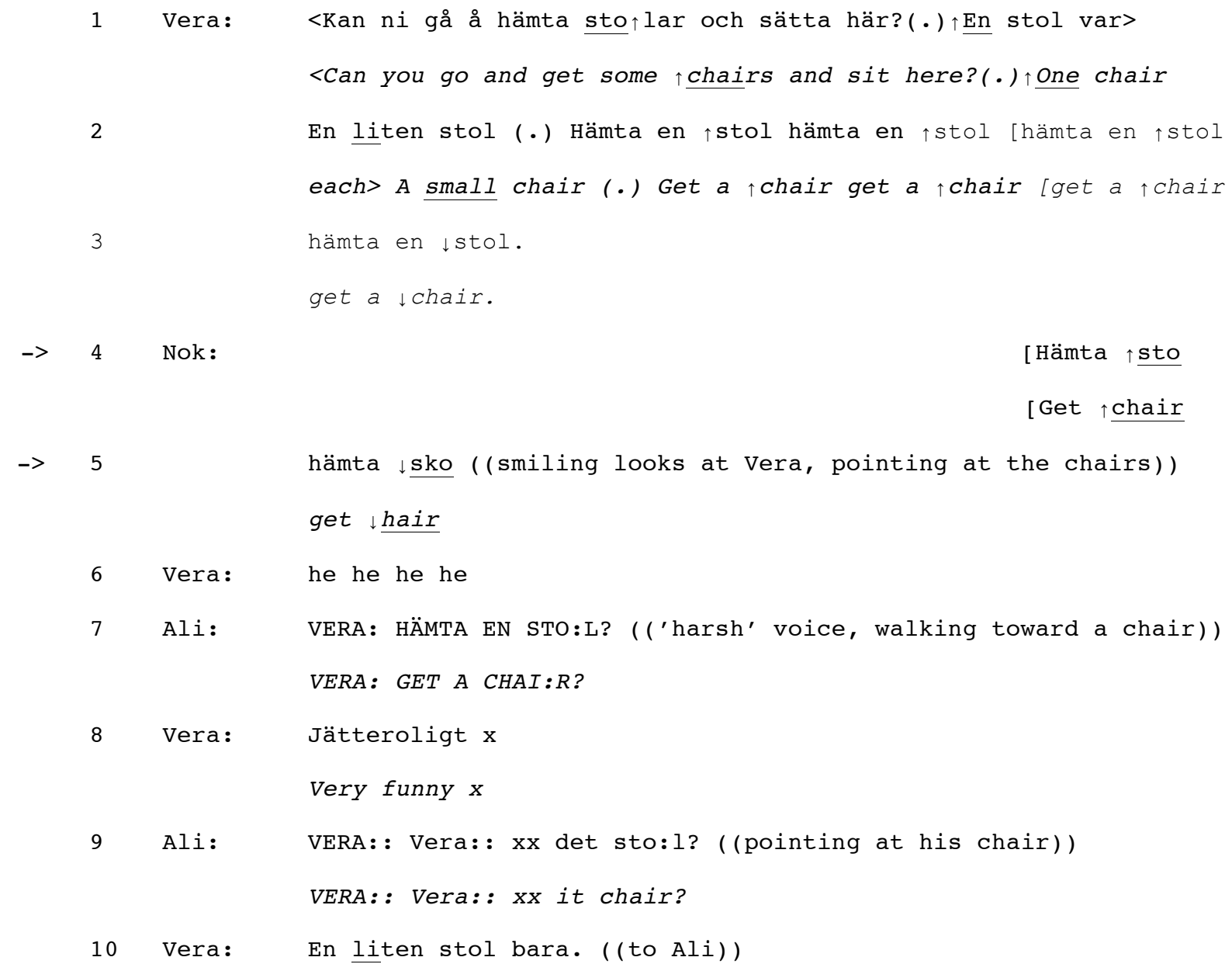


This episode starts when the teacher Vera tells the children to move some chairs to another area in the classroom. In lines 4 and 5, Nok recycles Vera's talking, when repeating her directive 'hämta stol!' ('get chair!). It involves a format tying in that she looks at the teacher smilingly, and gesticulates in a playful way, while talking. The intonational contour of her directive is modeled on the teacher's prior turn in that it recycles its stress, intonation and tempo. Nok's directive is produced synchronically with the teacher's and is accomplished as something of a coordinated choral performance.

Thus, her joking is accomplished through a fairly accurate performance of the 'teacher' that is keyed as a playful joking invitation (note her smile). Thereby, the words ('hämta sto hämta sko') and actions (decisive pointing) of the teacher change in meaning into a subversive impersonation in that the teacher's directive is now exploited for entertainment. In fact, Nok acts as an animator (Goffman, 1981) of the teacher's authoritative directive, positioning herself as a teacher as it were. The teacher's uptake (laughter in line 6) and positive evaluation 'jätteroligt' ('very funny', line 8) indicates her alignment with Nok's joking performance. The incongruency (here: hierarchical distance) between the animator, who performs the animation (the parodic imitation) and the 'principle', that is 'whose position is established by words spoken' (Goffman, 1981: 144) provides for the humorous change of footing in this episode.

In a classroom context, it is the teacher's prerogative to issue orders. When pupils issue order, as in the present case, this can be seen as something of a joke, an incongruous event within the normal routines of classroom life. What is striking, though, is that such jokes can be made at a very early stage of L2 acquisition in that the 
speaker needs only recast what has just been said by the teacher. There are but minimal demands on vocabulary search and active knowledge of L2, Swedish.

A closer look at Nok's format tying (lines 4 and 5) reveals, that her utterance is not an exact lexical imitation of the teacher's talk. Rather, it is based on intonational and phonological resemblance to the teacher's utterance. In fact, Nok's utterance is partly a 'nonsensical' one in that she recycles the teacher's intonation pattern, but not the exact wording of the phrase (e.g she ends up saying 'sko'instead of 'stol'). In work on early L2 interactions, several studies have demonstrated that it is shared background knowledge rather than participants' recognition of linguistic forms that accounts for achieving understanding (Gass and Varonis, 1991; Saville-Troike and Kleifgen, 1986; interactional sociolinguistics (Gumperz, 1982), and instances of miscommunication (Sarangi and Roberts, 2002). For instance, Saville-Troike and Kleifgen (1986) have shown that the children's shared knowledge of 'scripts for school' constituted sufficient information for the interpretation of meaning in dilingual conversations, that is, communication between speakers of two different languages, who do not mutually understand each other.

The following example provides another instance of the children's appropriation of teacher talk (register) in peer group interaction. During this episode, the children were playing Memory (picture labelling) on their own.

Ex. 6. (0209. 1153) Participants: children: Hiwa (8, boy.), Rana (8, girl), Layla (10, girl), Fusi (7, girl.) and the researcher A.

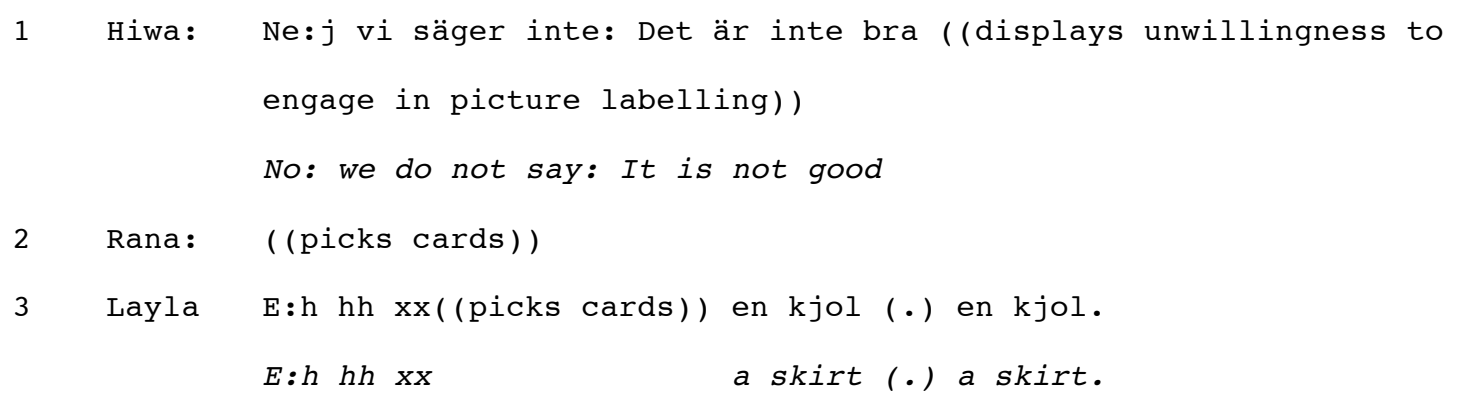




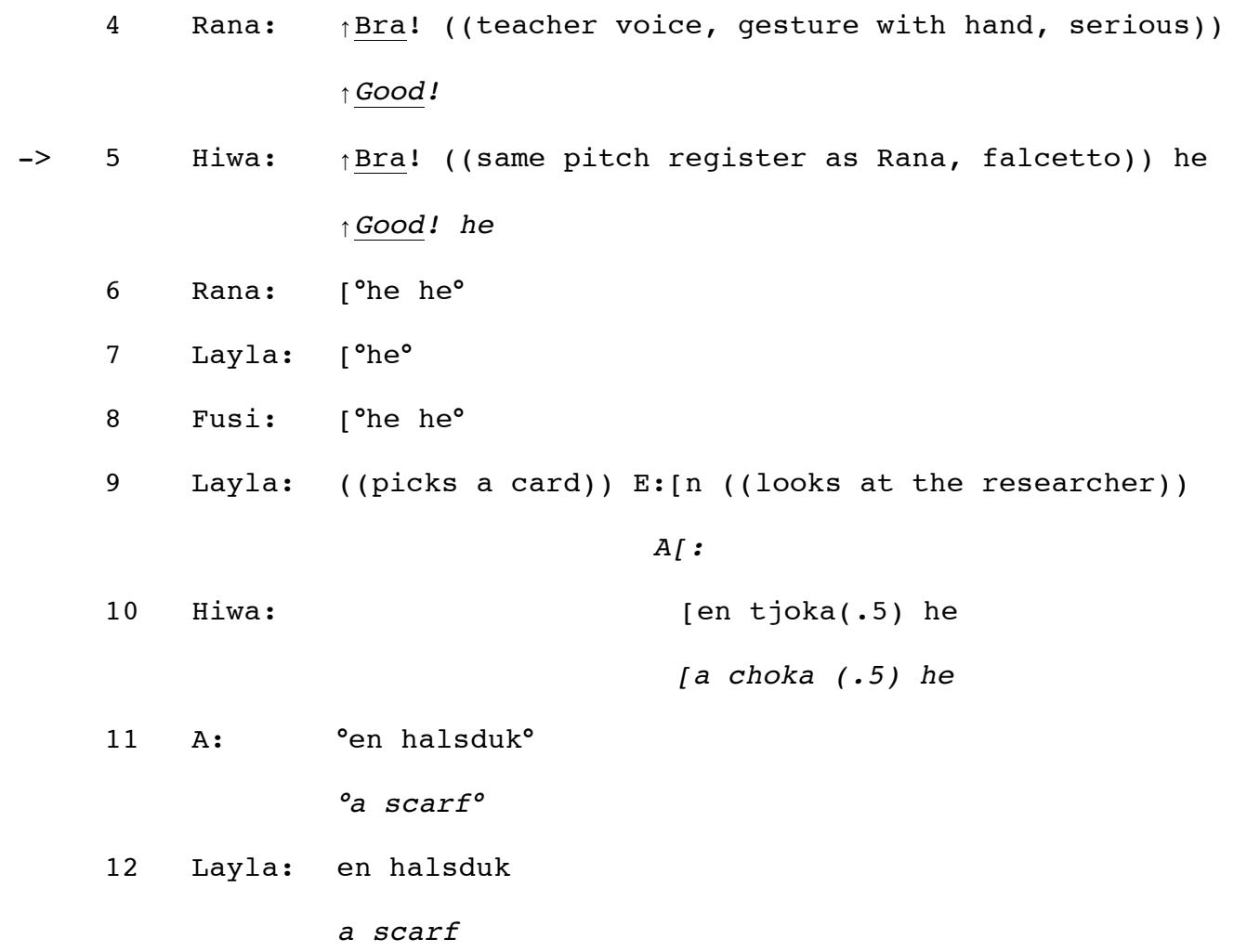

In line 4, Rana presents a positive evaluation of Layla's successful move (she picked a matching pair of cards). Rana deploys a 'teacher's voice', delivering her talk in a serious mode (note, no smiling face). Also, the very act of doing evaluation is prototypical of teacher moves as has been discussed in work on Initiative-Response-Evaluation in school contexts (Sinclair and Coulthard, 1975; see also the teacher' s positive evaluation 'jätteroligt' ('very funny') in Ex. 5). Her utterance is accomplished as a subversive stylization of teacher talk (Bakhtin, 1978), that is, as an appropriation of another person's style in such a way that the voice carries the author's original set of viewpoints and evaluation (Bakhtin, 1978: 181). Thereby, her positive evaluation can be seen to function as a teacher move, that is, as an enactment of the teacher's rights and responsibilities. The other participants apparently interpret her positive evaluation as comic (inappropriate) because another child, Hiwa, immediately produces a humorous tease, recycling the surface structure of the prior utterance in a falsetto voice (line 5). Moreover, his recycling of the original utterance is accomplished 
as an exact prosodic repetition, in that he recycles, not only Rana's utterance, but also its high pitch and intonation, using 'absolute register matching' (Couper-Kuhlen, 1996).

Imitations of the way words are spoken can be seen to constitute parody in a Bakhtinian sense (cf. Couper-Kuhlen, 1996), 'a battlefield for opposing intentions' when the speaker employs the speech of the other and implants 'an intention that is directly opposed to the original one' (Bakhtin, 1978:185). Thus, by imitating the way the words are spoken, Hiwa can be seen to make an implicit humorous commentary on Rana's appropriation of teacher authority within peer group interaction. The joking character of his parodic imitation of Rana is acknowledged in that the three girls simultaneously burst into shared laughter (lines 6-8). It can be noted that Rana is laughing along with the others, playing along with the tease, rather than defending herself, which is something that requires pragmatic skills (Tholander and Aronsson, 2002).

Indirectly, Hiwa's teasing of Rana addresses her entitlement to a teacher voice. In the present classroom community, mild mockings recurrently involved an alertness to language form in that the pupils would, for instance, create parodic repetitions of coparticipants' nonnative pronounciation or some other minor or major grammatical mistake. In the present case, it can be seen how the children were quite alive to violations of implicit pragmatic norms. Moreover - in both cases (lines 4 and 5) - such mockings simultaneously involved an awareness of implicit pragmatic rules in that the focus was on how something was said, on style, rather than on the message as such.

The appropriation of some other person's words may draw upon recyclings in the immediate sequential context of talk (Examples 1, 2, 5 - 6). On other occasions, the present children also incorporated teacher register in what Johnstone (1994) has called 'distant repetitions' of prior discourse (cf. Example 4) or enactment of classroom 
routines (e.g. counting, Example 3) and other instances of what Blum-Kulka et.al. (this volume) have called 'mocking subversion', as in their example of children's irreverent singing during independence day celebrations. In phrases such as 'Little Fare', an endearment routine is recycled in a subversive direction, in that it is addressed to a superior party in a type of playful role reversal. In their joking exploitation of the teacher talk - register, the children simultaneously displayed pragmatic awareness of local norms for language use.

\section{Concluding discussion}

In the present data, both intertextual play and role appropriations were based on recyclings, exploiting the imitation of other voices (cf. Bakhtin, 1978, 1981). Playful recyclings thus formed an inherent part of classroom competence. In earlier work, repetition has been studied as a conversational strategy for achieving topical coherence in conversation, as in Keenan's (1977) or Pallotti's (2000) work. As illustrated by the present study (cf. Goodwin and Goodwin, 1987; Hopper, 1992), format tyings and other repetitions can also be deployed to express novel audience alignments. In fact, the majority of the present episodes (all but Examples 3 and 4, which draw on formulaic expressions) illustrate how format tying was an important resource in creating classroom entertainment (e.g. joking events). Recurrently, recyclings were accomplished as parodic imitations of previous speakers (Examples 5 and 6) thereby illustrating the children's sensitivity to social order. The present study thus showed that format tying was an important device for rearranging social relations within a classroom community, both in terms of participation frameworks (alignments), and mode (serious, nonserious). 
The children's playful recyclings inventively explored prior classroom conversations, and featured parodic imitations of what in Bakhtinian terms may be called 'authoritative discourse' (1981: 345). Appropriations of teacher talk involved not only teachers' prior utterances and actions but also recycling of teacher talk register. The resources, the children drew upon in joking events were thus clearly stamped with the mark of their shared classroom biography. In the present context, intertextual play and role appropriations both involve recyclings which can be seen as secondary adjustments (Goffman, 1961), that is, creative transformations of classroom routines on the part of the children. The participants' shared knowledge of daily routines (e.g. singing, doing math) thus provided meaningful frameworks for creating playful and joking interactional events (Examples 1-3). As seen in our data, the notion of L2 learning is thus not only applicable to learning practices in formal teaching in the classroom, but also to the spontaneous creative use of teaching for some totally different purposes. Recycling of knowledge in order to have fun seems to be a part of learning practices in the present classroom community (see also Rampton (1999). It is obvious, that the formal teaching situations lend themselves to a variety of more or less subversive uses.

The findings of the present study indicate that metapragmatic play focuses on how something is said. This can be seen in intertextual recyclings (Examples 1-3) and nonsense forms (Example 1) and in role appropriations, which all draw on the situational humor or playing off teacher-student hierarchies (Examples 4- 6). Our first three examples (intertextual joking) all illustrate that it is 'funny' when something is said, for instance, in a novel and incongruent context (e.g. conversation and not a singing or math routine), whereas the last three examples illustrate pragmatic comments on by whom something is said; e.g. how contributions are subversely embedded in 
teacher talk prosody or authoritative classroom gestures, thereby inverting classroom hierarchies.

Such joking recyclings can be seen as a pleasurable 'time-out' which temporarily frees participants from the tedious business of language learning and 'reality work' (Flaherty, 1984) thereby creating free zones within classroom order or 'creative frame play' (van Dam, 2002). Yet, all cases of joking events (metapragmatic play) were neatly designed as detailed comments on language activities in a L2 classroom, drawing on those very activities. On a theoretical note (invoking language socialization perspectives), it can therefore also be deduced that joking activities as such (both intertexual recyclings and role appropriations) do sensitize children to both pragmatic and formal linguistic aspects of second language use (e.g. phonology morphology). When parodying and joking, the children can thus simultaneously be seen to advance their language awareness and their knowledge of social norms (Ochs, 1988).

Although joking events in the present classroom were frequently modelled as appropriations of teacher talk or (and were even, at times, subversively addressed to the teacher), the analyses extend beyond the dyadic teacher-student interactional pattern traditionally invoked in classroom research. In the present investigation, appropriations of teacher talk took place in a variety of participation frameworks, involving different participant constellations, such as peer groups (Example 6), teacher-student dyads (Example 5) and groups involving peers and teacher (Examples 2, 4). Subversive appropriations of teacher talk were recurrently designed as loud or exaggerated public performances for the larger classroom audience (e.g. Examples 2, 4 and 6), thereby indicating that the joking was based on pragmatic awareness and pragmatic skills, handling a complex multiparty environment, the classroom community, involving both peers and teachers. 
Like those discussed by Duff (2000), the present children spontaneously employed repetition in their use of L2. Format tyings and other repetitions provided easily accessible minimalistic means to join into classroom activities and were therefore extensively exploited as ways to enter ongoing interactions. The present pupils were all just beginning to speak Swedish. Yet, by using format tyings and other recyclings of prior talk or classroom texts, they managed to entertain peers in such a way that they secured their attention and created numerous occasions for informal conversations. Of course, they could probably only manage this because they were all basic level speakers. Native Swedish conversations would perhaps have offered considerably fewer entry points for them.

Within the multiparty format of classroom conversations, the children were thus able to creatively reframe the official business of routine tasks into joking encounters. Thereby, they also managed to consolidate the classroom community as a L2, Swedish, speaking group. Peer group recyclings thus created meaningful contexts for the acquisition of linguistic and pragmatic skills (cf. Snow and Blum-Kulka, 2002; Goodwin, 1990). Moreover, the children simultaneously learned to create and provide culturally appropriate forms and occasions for joking, as a distinctive form of social interaction (Flaherty, 1984; cf. Simmel, 1971: 25).

\section{TRANSCRIPTION NOTATIONS}

: $\quad$ : prolonged syllable

[ ] : demarcates overlapping utterances

(.) : micropause, i.e. shorter than (0.5)

(2) : numbers in single parentheses represent pauses in seconds

AMP : relatively high amplitude

$\mathrm{X} \quad$ : inaudible word

(xx) : unsure transcription:

dach : nonsense words

$\circ \quad$ : speech in low volume

(( )) : comments of the transcriber

$><\quad$ : quicker pace than surrounding talk

$<>\quad$ : slower pace than surrounding talk

? $\quad$ : rising terminal intonation

. $\quad$ : falling terminal intonation

$\uparrow \quad$ : rising intonation

$\downarrow \quad$ : falling intonation 
$=\quad:$ latching between utterances

Fare : sounds marked by emphatic stress are underlined

he : laughter (used for both Swedish and English dialogue)

\section{REFERENCES}

Aronsson, K. and Thorell, M. (2002). 'Voice and collusion in adult.child talk. Toward an architecture of intersubjectivity', in S. Blum-Kulka and C. E. Snow (eds) Talking to adults. The contribution of multiparty discourse to language acquisition, pp. 277-293. Mahwah, NJ: Lawrence Erlbaum.

Bakhtin, M. (1981) The Dialogic Imagination. Holquist, M. (ed.). Austin: University of Texas Press.

Bakhtin, M. [1929] (1978) 'Discourse typology in prose' in L. Mateika and K. Pomorska (eds) Reading in Russian Poetics. Formalist and Structuralist views, pp. 176-196. Ann Arbor: University of Michigan Press.

Bjorklund, D. F. (1989) Children's Thinking. Developmental Function and Individual Differences. Brooks/Cole Publishing Company.

Brown, P. (2000) 'Conversational Structure and Language Acquisition: The Role of Repetition in Tzeltal', Journal of Linguistic Anthropology 8: 197-221.

Cathcart-Strong, R. (1986) 'Input generation by young second language learners', TESOL Quarterly 20: 515-530.

Cazden, C. (1988) Classroom Discourse: The Language of Teaching and Learning. Portsmouth, NH: Heinemann.

Cekaite, A. and Aronsson, K. (2002) 'Joking genres in young children's interactions'. Paper presented at the 2002 International Congress for the Study of Child Language, Madison, Wisconsin.

Chukovsky, K. [1928] (1963) From Two to Five. (Translated and edited by M. Morton). Berkeley: University of California Press.

Cochran-Smith, M. (1984/1994) The Making of a Reader. Norwood, NJ: Ablex.

Cook, G. (2000) Language Play, Language Learning. Oxford University Press.

Corsaro, B. and Maynard, D. (1996) 'Format tying in discussion and argumentation among Italian and American children' in in D. Slobin et al. (eds) Social interaction, Social context, and language. Essays in honor of Susan Ervin-Tripp, pp. 157-174. Mahwah, NJ: Lawrence Erlbaum.

Couper-Kuhlen, E. (1996) 'The prosody of repetition: on quoting and mimicry', in E. CouperKuhlen and M. Selting (eds) Prosody in conversation. Interactional studies, pp. 366405. Cambridge: Cambridge University Press.

Cromdal, J. and Aronsson, K. (2000) 'Footing in bilingual play', Journal of Sociolinguistics 4: $435-457$.

Douglas, M. (1968) 'The social control of cognition: some factors in joke perception', Man 3: 361- 376.

Duff, P. A. (2000) 'Repetition in foreign language classroom interaction', in J. K. Hall and L. S. Verplaetse (eds) Second and Foreign Language Learning through Classroom Interaction, pp. 109-139. Mahvah, NJ: Lawrence Erlbaum.

Flaherty, M. G. (1984) 'A formal approach to the study of amusement in social interaction', in Studies in Symbolic Interaction, pp. 71-81. NY: JAI Press. 
Garrett, P. B. and Baquedano-Lopez, P. (2002) 'Language socialization: Reproduction and continuity, transformation and change' Annual Review of Anthropology, 31: 339-61.

Gass, S. M. and Varonis, E. M. (1991) 'Miscommunication in Nonnative speaker discourse', in N. Coupland, et al. (eds) "Miscommunication" and Problematic Talk, pp. 121-145. London: Sage Publications.

Glenn, P. J. (1989) 'Initiating shared laughter in multi-party conversations', Western Journal of Speech communication, 53: 127-149.

Goffman, E. (1959) The presentation of self in everyday life. New York: Doubleday Anchor Books.

Goffman, E. (1961) Asylums. New York: Doubleday.

Goffman, E. (1974) Frame analysis. New York: Harper \& Row.

Goffman, E. (1981) Forms of Talk. Cambridge: Harvard University Press.

Goodwin, M. H. and Goodwin, C. (1987) 'Children's arguing', in S. Philips, et al. (eds) Language, gender, and sex in comparative perspective, Studies in the social and cultural foundations of language, pp. 200-248. NY: Cambridge University Press.

Goodwin, M. H. (1990) He-said-she-said: Talk as Social Organization among Black Children. Bloomington and Indianapolis: Indiana University Press.

Gumperz, J. (1982) Discourse Strategies. Cambridge: Cambridge University Press.

Hay, J. (2001) 'The pragmatics of humor support', Humor 14: 55-82.

Heath, S.B. (1978) Teacher Talk: Language in the Classroom. Washington, DC: Center for Applied Linguistics.

Hopper, R. (1992) Telephone Conversation. Bloomington: Indiana University Press.

Hopper, R. and Glenn, P. (1994) 'Repetition and play in conversation' in Johnstone, B. (ed.): Repetition in Discourse: Interdisciplinary perspectives. Vol. II, pp. 29-40. Norwood, NJ: Ablex Publishing Corporation.

Jefferson, G. (1979) 'A technique for inviting laughter and its subsequent acceptance/declination' in Psathas (ed.): Everyday Language: Studies in Ethnometodology, pp. 79-96. New York: Irvington.

Jefferson, G. (1996) 'On the poetics of ordinary talk', Text and Performance Quarterly 16: 161.

Johnstone, B., ed. (1994): Repetition in Discourse: Interdisciplinary perspectives. Vol. I Norwood, NJ: Ablex Publishing Corporation.

Kanagy, R. (1999) 'Interactional routines as a mechanism for L2 acquisition and socialization in an immersion context' Journal of Pragmatics 31: 1467-1492.

Keenan, E. (1977) 'Making it last: Repetition in children's discourse', in S.Ervin-Tripp and C. Mitchell-Kernan (eds) Child Discourse, pp. 125-139. New York: Academic Press.

Kristeva, J. (1967) 'Bakhtine, le mot, le dialogue et le roman' [Bakhtin, the word, the dialogue and the novel], Critique, 23: 438-465.

Lampert, M. D. (1996) 'Studying gender differences in the conversational humor of adults and children', in D. Slobin et al. (eds) Social interaction, Social context, and language. Essays in honor of Susan Ervin-Tripp, pp.579-596. Mahwah, NJ: Lawrence Erlbaum.

Lave, J. and Wenger, E. (1991) Situated Learning: Legitimate Peripheral Participation. Cambridge: Cambridge University Press.

McGhee, P. E. (1976) 'Children's appreciation of humor: A test of the cognitive congruency principle', Child development 47: 420-426.

McLaughlin, B. (1987) Theories of Second Language Acquisition. London: Arnold. 
Ochs, E. (1988) Culture and Language Development: Language acquisition and language socialization in a Samoan village. Cambridge: Cambridge University Press.

Opie, I. and Opie, P. (1959) The Lore and Language of School Children. Oxford: Oxford University Press.

Pallotti, G. (2000) 'External appropriation as a strategy for participation in intercultural multiparty conversations', in A. Di Luzio, et al. (eds) Culture in communication, pp. 295-334. Amsterdam: John Benjamin.

Potter, J. (1997) 'Discourse analysis as a way of analysing naturally occurring talk ', in D. Silverman (ed.) Qualitative research. Theory, method and practice, pp. 144-160. London: Sage.

Rampton, B. (1999) 'Inner London Deutsch and the animation of an instructed foreign language', Journal of Sociolinguistics 3: 480-504.

Rampton, B. (2002) 'Ritual and foreign language practices at school', Language in Society 31: 491-525.

Reddy, M. (1979) 'The conduit metaphor: A case of frame conflict in our language about language', in A. Ortony (ed.) Metaphor and Thought pp. 284-324. Cambridge: Cambridge University Press.

Rogoff, B. (1990) Apprenticeship in Thinking: Cognitive Development in Social Context. New York: Oxford University Press.

Sacks, H. (1992) Lectures on Conversation. vol. I , II. Oxford: Basil Blackwell.

Sarangi, S and Roberts, C. (2002) 'Discoursal (mis)alignments in professional gatekeeping encounters', in C. Kramsch (ed) Language Acquisition and Language Socialization pp. 197-228. London: Continuum.

Saville-Troike, M. and Kleifgen, J. (1986) 'Scripts for school. Cross-cultural communication in elementary classrooms', Text 6: 207-221.

Schegloff, E. A. (2001) 'Getting serious: Joke -> serious 'no', Journal of Pragmatics 33: 1947-1955.

Schieffelin, B. (1990). The give and take of everyday life. Language socialization of Kaluli children. Cambridge: Cambridge University Press.

Schwartzman, H. (1978) Transformations. The anthropology of children's play. New York: Plenum Press.

Simmel, G. (1971). 'On individuality and social forms: selected writings' in D. N Levine (ed). Chicago: University of Chicago Press.

Sinclair, J. and Coulthard, R. M. (1975) Towards the analysis of discourse: The English used by teachers and pupils. London: Oxford University Press.

Snow, C.E. and Blum-Kulka, S. (2002). 'From home to school. School-age children talking with adults'in S. Blum-Kulka and C. E. Snow (eds), Talking to adults. The contribution of multiparty discourse to language acquisition, pp. 327-341. Mahwah, NJ: Lawrence Erlbaum

Sullivan, P. N. (2000) 'Spoken artistry: performance in second language classroom' in Hall, J. K. and L. S. Verplaetse (eds) Second and Foreign Language Learning through Classroom Interaction, pp. 73-91. Mahvah, NJ: Lawrence Erlbaum.

Tholander, M. and Aronsson, K. (2002). 'Teasing as serious business. Collaborative staging and response work', Text, 22:1-37.

van Dam, J. (2002) 'Ritual, face, and play in a first English lesson' in Kramsch, C. (ed.) Language Acquisition and Language Socialization, pp. 237-266. London: Continuum.

van Dam van Isselt, H. R. (1993) "Her name is - uh dat weet ik niet." Authenticity in the L2 classroom. Unpublished PhD dissertation, University of Amsterdam. 
Willet, J. (1995) 'Becoming first graders in an L2. An ethnographic study of L2 socialization’, TESOL Quarterly 29: 473-503. 